\title{
The Use of Selenium Enriched Enterococcus faecium as an Alternative Selenium Source for Growing-finishing Pigs
}

\author{
Martin Svoboda ${ }^{1}, Z_{\text {deněk Fajt }}{ }^{1}$, Tomáš Baňoch ${ }^{1}$, Josef Drábek ${ }^{1}$, Alena Saláková ${ }^{2}$ \\ ${ }^{1}$ Swine Clinic, Faculty od Veterinary Medicine, ${ }^{2}$ Department of Meat Hygiene and Technology, \\ Faculty of Veterinary Hygiene and Ecology, University of Veterinary \\ and Pharmaceutical Sciences Brno, Czech Republic
}

Received April 1, 2010

Accepted June 15, 2010

\begin{abstract}
The aim of the study was to evaluate the effect of the feeding of selenium enriched Enterococcus faecium on selenium concentrations in muscle tissue and on meat quality indicators in finishing pigs. Groups of pigs fed Se-enriched E. faecium $(\mathrm{n}=12)$, sodium selenite $(\mathrm{n}=12)$ and Se-enriched yeast $(n=12)$ were used in the study. The tested feed mixtures were fed for a period of 3 months before the pigs were slaughtered. The selenium concentrations in muscle tissue achieved by the use of Seenriched $E$. faecium were comparable to those achieved in sodium selenite diets and lower $(p \leq 0.05)$ compared to Se-enriched yeast. Concentration of Se in serum and glutathione peroxidase (GSH-Px) activities did not differ in animals fed different Se forms. No differences in indices of meat quality were found among the groups. Se-enriched E. faecium bacteria can be recommended as an alternative selenium source for finisher pigs with the similar efficacy as sodium selenite.
\end{abstract}

Pork, meat quality, selenomethionine, selenocysteine

Selenium has an important antioxidant role as a part of enzyme glutathione peroxidase (Sunde 1994). Several studies in human medicine provided evidence for the efficacy of selenium as an anticancer agent (Duffield-Lillico et al. 2003). Selenium also enhances immune functions (Beck et al. 2001) and has an important role in the maintenance of fertility (Rayman 2000). It has been documented that pork can contribute significantly to the selenium intake in human population (Kadrabová et al. 1996; Fajt et al. 2009).

Selenium deficiency in pigs is manifested as mulberry heart disease, hepatosis dietetica and muscular dystrophy (Lindberg et al. 1972). Selenium requirements of growingfinishing pigs can be achieved by providing selenium either from an inorganic or an organic source. Sodium selenite represents the inorganic form. Selenium from Se-enriched yeast is the most commonly used organic selenium form (Schrauzer 2000).

Experiments in growing-finishing pigs revealed higher accumulation of organic $\mathrm{Se}$ compared to inorganic form in tissues (Mahan and Parrett 1996; Taylor et al. 2005). Also experiments in sows demonstrated higher Se content in newborn piglets tissues and in colostrum when the Se-enriched yeast was used (Mahan and Peters 2004).

Limited data are available so far regarding the use of other organic selenium sources in pigs. For instance Se from Se-enriched alga Chlorella spp. (Svoboda et al. 2009b) and soybean based selenium proteinate (Jang et al. 2006) were used as alternative selenium sources in finishing swine.

The aim of the present study was to evaluate the effects of Se from Se-enriched Enterococcus faecium on tissue selenium retention and meat quality indicators in growingfinishing pigs.

\section{Materials and Methods}

Experimental design

A total of 36 pigs were used in our experiment. Only female pigs were used. The experiment started at the beginning of the grower phase of production. Before the experiment, all pigs were fed an identical diet

Address for correspondence:

Doc. MVDr. Marin Svoboda, Ph.D.

Swine Clinic, Faculty of Veterinary Medicine

University of Veterinary and Pharmaceutical Sciences Brno

Palackého 1/3, 61242 Brno, Czech Republic

Phone: +420 541562433

E-mail: svobodama@vfu.cz

http://www.vfu.cz/acta-vet/actavet.htm 
Table 1. Percentage composition of the feed mixture $\mathrm{A} 1$

\begin{tabular}{|l|c|}
\hline Ingredient & Percentage \\
\hline Zeofeed & 1.0 \\
\hline Wheat & 24.5 \\
\hline Corn & 21.5 \\
\hline Barley & 25.0 \\
\hline Soya bean pollard & 20.0 \\
\hline Yeast Bitec Q & 2.0 \\
\hline Nutrimilk feed & 0.8 \\
\hline Soya bean oil & 0.9 \\
\hline Limestone & 1.7 \\
\hline $\begin{array}{l}\text { Minfos MDCP20 } \\
\text { (monodicalciumphosphate) }\end{array}$ & 0.7 \\
\hline NaCl & 0.4 \\
\hline Trace mineral and vitamin premix & 2.0 \\
\hline
\end{tabular}

Supplied per $\mathrm{kg}$ of diet: $0.30 \mathrm{mg}$ of Se, $0.25 \mathrm{mg}$ of $\mathrm{Co}, 5.00 \mathrm{mg}$ of $\mathrm{Cu}, 40.00 \mathrm{mg}$ of $\mathrm{Fe}, 0.38 \mathrm{mg}$ of I, $15.00 \mathrm{mg}$ of $\mathrm{Mn}, 45.00 \mathrm{mg}$ of $\mathrm{Zn}, 5.00 \mathrm{mg}$ of calcium pantothenate, 3500.00 I.U. of vit. A, 625.00 I.U. of vit. D3, $20.00 \mathrm{mg}$ of vit. E, $0.75 \mathrm{mg}$ of vit. K3, $0.75 \mathrm{mg}$ of vit. B1, $2.10 \mathrm{mg}$ of vit. B2, $1.00 \mathrm{mg}$ of vit $\mathrm{B} 6,0.013 \mathrm{mg}$ of vit. $\mathrm{B} 12,7.50 \mathrm{mg}$ of niacinamide, $0.025 \mathrm{mg}$ of biotin, $50.00 \mathrm{mg}$ of cholinchlorid, $0.10 \mathrm{mg}$ of folic acid, $25 \mathrm{mg}$ of Natuphos, $0.175 \mathrm{~g}$ of L-lysine, $0.076 \mathrm{~g}$ of L-threonine, $0.048 \mathrm{~g}$ of D-Lmethionine, $0.0045 \mathrm{~g}$ of L-tryptophan

Table 2. Percentage composition of the feed mixture A2

\begin{tabular}{|l|c|}
\hline Ingredient & Percentage \\
\hline Zeofeed & 1.0 \\
\hline Wheat & 28.0 \\
\hline Corn & 21.4 \\
\hline Barley & 24.0 \\
\hline Soya bean pollard & 19.5 \\
\hline Soya bean oil & 0.9 \\
\hline $\begin{array}{l}\text { Minfos MDCP20 } \\
\text { (monodicalciumphosphate) }\end{array}$ & 0.7 \\
\hline Limestone & 1.6 \\
\hline NaCl & 0.4 \\
\hline Kalama (benzoic acid) & 0.5 \\
\hline Trace mineral and vitamin premix & 2.0 \\
\hline
\end{tabular}

Supplied per kilogram diet: $0.30 \mathrm{mg}$ of Se, $0.25 \mathrm{mg}$ of $\mathrm{Co}, 5.00 \mathrm{mg}$ of $\mathrm{Cu}, 35.00 \mathrm{mg}$ of $\mathrm{Fe}, 0.38 \mathrm{mg}$ of $\mathrm{I}$, $15.00 \mathrm{mg}$ of $\mathrm{Mn}, 45.00 \mathrm{mg}$ of $\mathrm{Zn}, 4.50 \mathrm{mg}$ of calcium pantothenate, 3000.00 I.U. of vit. A, 495.00 I.U. of vit. $\mathrm{D} 3,17.60 \mathrm{mg}$ of vit. E, $0.60 \mathrm{mg}$ of vit. $\mathrm{K} 3,0.65 \mathrm{mg}$ of vit. $\mathrm{B} 1,2.10 \mathrm{mg}$ of vit. $\mathrm{B} 2,0.90 \mathrm{mg}$ of vit. $\mathrm{B} 6,0.013 \mathrm{mg}$ of vit. B12, $6.50 \mathrm{mg}$ of niacinamide, $0.026 \mathrm{mg}$ of biotin, $50.00 \mathrm{mg}$ of cholinchlorid, $25 \mathrm{mg}$ of Natuphos, $0.149 \mathrm{~g}$ of L-lysien, $0.064 \mathrm{~g}$ of L-threonine, $0.03 \mathrm{~g}$ of D-Lmethionine, $0.004 \mathrm{~g}$ of L-tryptophan supplemented with $0.3 \mathrm{mg} \cdot \mathrm{kg}^{-1} \mathrm{Se}$ in the form of sodium selenite. The compositions of experimental mixtures are presented in Table 1 and Table 2. The feed mixtures were composed of a basal diet and a mineral supplement. The pigs received experimental mixtures for the period of 3 months before the slaughter. The feed mixture A1 was administered during the first 30 days. The feed mixture A2 was given to pigs for the rest 60 days.

The pigs were divided into 3 equal groups of 12 animals.

In group A $(n=12)$ pigs were fed feed mixtures A1 and A2 supplemented with organic selenium at the dose of $0.3 \mathrm{mg} \cdot \mathrm{kg}^{-1}$ in the form of Se-enriched Enterococcus faecium.

The group $\mathrm{B}(\mathrm{n}=12)$ had feed mixtures A1 and A2 supplemented with inorganic sodium selenite at the dose of $0.3 \mathrm{mg} \cdot \mathrm{kg}^{-1}$.

In group $\mathrm{C}(\mathrm{n}=12)$ the pigs received feed mixtures $\mathrm{A} 1$ and A2 with the addition of organic selenium in the form of Seenriched yeast $\left(0.3 \mathrm{mg} \cdot \mathrm{kg}^{-1}\right)$.

The experiment was approved by the Ethics Committee of the University of Veterinary and Pharmaceutical Sciences, Brno, Czech Republic.

\section{Sampling}

The blood samples were taken from all pigs at the beginning of the trial and one day before the slaughter. The pigs were bled from vena cava jugularis. Serum was collected and frozen for further analysis.

Tissue samples for selenium determination (heart, musculus biceps femoris, liver and ovaries) were taken after the slaughter and frozen for further analysis. Muscle samples for the evaluation of the meat quality indicators were taken from musculus biceps femoris (300 g).

Determination of Se in tissues (heart, liver, muscle, ovaries)

The samples for selenium determination were mineralized in a closed system using a microwave (MLS-1200, Milestone, Italy) digestion technique with $\mathrm{HNO}_{3}$ and $\mathrm{H}_{2} \mathrm{O}_{2}$. The samples were evaporated and the mineral residue was dissolved in water to which $20 \% \mathrm{HCl}$ was added. Selenium content was then determined with Solar 939 AA Spectrometer (Unicam, UK) using a hydride AAS technique.

\section{Determination of GSH-Px activities in serum}

The method of Paglia and Valentin (1967) was used for GSH-Px activity measurements in serum. The test kit RANSEL (Randox Laboratories, Ltd., United Kingdom) was employed for this purpose.

\section{Meat quality indicators}

Meat colour was measured $24 \mathrm{~h}$ after slaughter. The colour was determined objectively by a Konica Minolta spectrophotometer CM-2600d with 8-mm-diameter measurement area, using the D65 illuminant and the $10^{\circ}$ standard observer. The instrument was calibrated against a white standard plate. The results were expressed in terms of lightness $\mathrm{L}^{*}$, redness a*, yellowness $\mathrm{b}^{*}$.

Samples were placed in a polyethylene bag, and cooked in water bath. Internal temperature of samples was maintained at $70{ }^{\circ} \mathrm{C}$ for $60 \mathrm{~min}$. After being cooled to room temperature, samples were weighed. Cooking loss was expressed as percentage weight difference between uncooked and cooked samples.

Drip loss percentage was determined as weight loss relative to $24 \mathrm{~h}$. 
The $\mathrm{pH}$ value was measured with a $\mathrm{pH}$-meter 340i WTW (WTW, Germany). The needle probe SenTix Sp was used.

Lipid oxidation-thiobarbituric number (TBARS) was determined spectrophotometricaly at $532 \mathrm{~nm}$ after distillation of the sample with vapour and reaction of distillate with 2-thiobarbituric acid in hot water bath (Castellini et al. 2002).

\section{Results}

The results of selenium concentrations in serum and of GSH-Px activities in serum are presented in Figs 1 and 2. No differences in serum selenium concentrations were found among the groups at the beginning of the trial. Before the slaughter, the two groups with organic form of selenium (Se-enriched yeast and Se-enriched E. faecium) did not differ

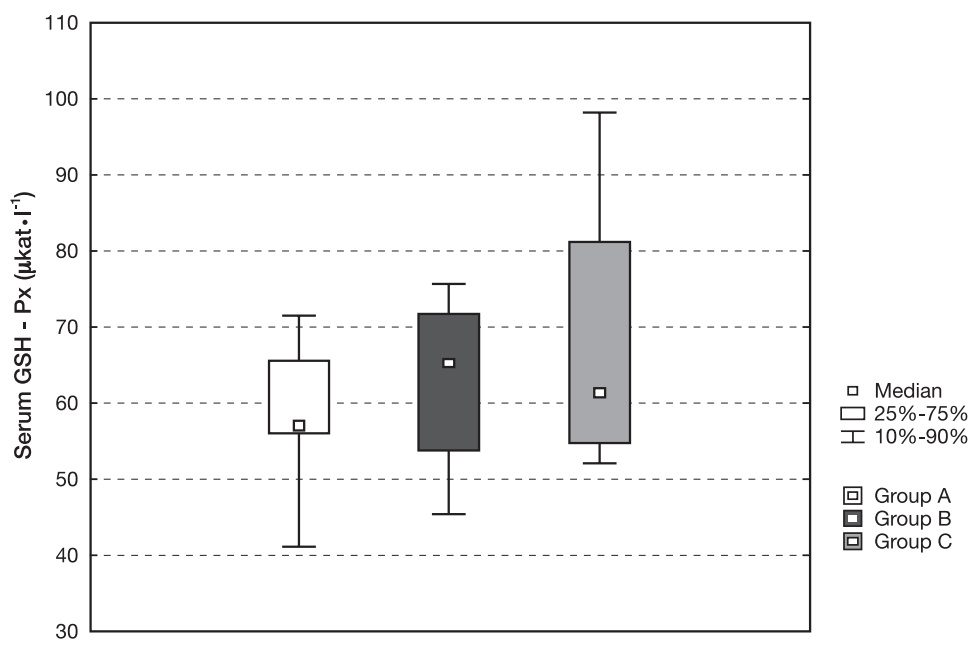

A - selenium enriched Enterococus faecium, B - sodium selenite, C - selenium enriched yeast

Fig. 1. Serum GSH-Px concentration

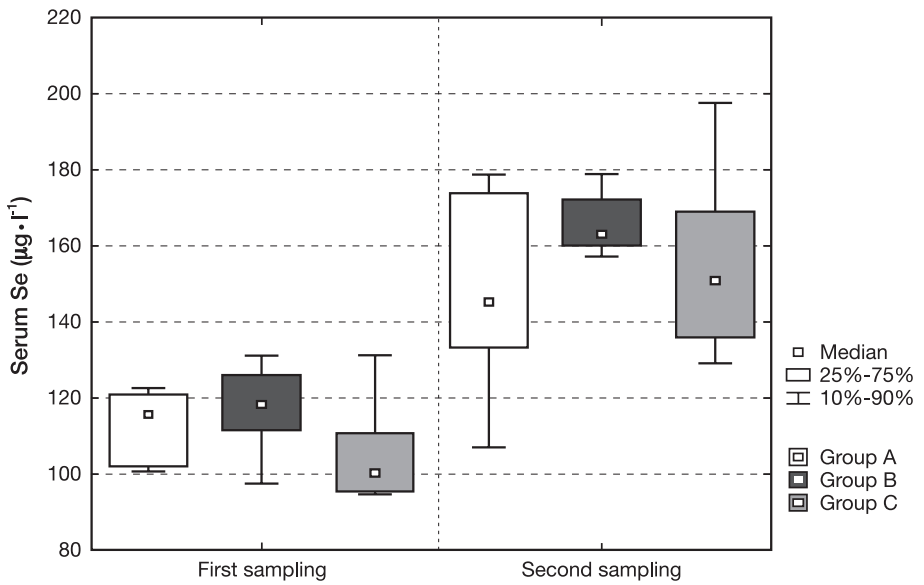

A - selenium enriched Enterococus faecium, B - sodium selenite, C - selenium enriched yeast

Fig. 2. Serum Se concentration 
in their serum Se concentrations and serum GSH-Px activities. The comparison between inorganic sodium selenite and two selenium in organic form groups did not reveal any significant difference either in Se serum concentrations or GSH-Px serum activities.

The group of pigs supplemented with inorganic sodium selenite had lower Se concentration in liver, heart and muscle tissues than the pigs fed with Se-enriched yeast. The use of Seenriched E. faecium resulted in Se concentrations in liver, heart and muscle comparable to inorganic sodium selenite group. However they were significantly lower $(p \leq 0.05)$ than in Se-enriched yeast supplemented group. In ovaries, the Se concentrations in pigs fed with inorganic sodium selenite were comparable to the both organic Se groups. The ovarial Se concentrations of E. faecium supplemented group were comparable to Se-enriched yeast group. The results are presented in Fig. 3.

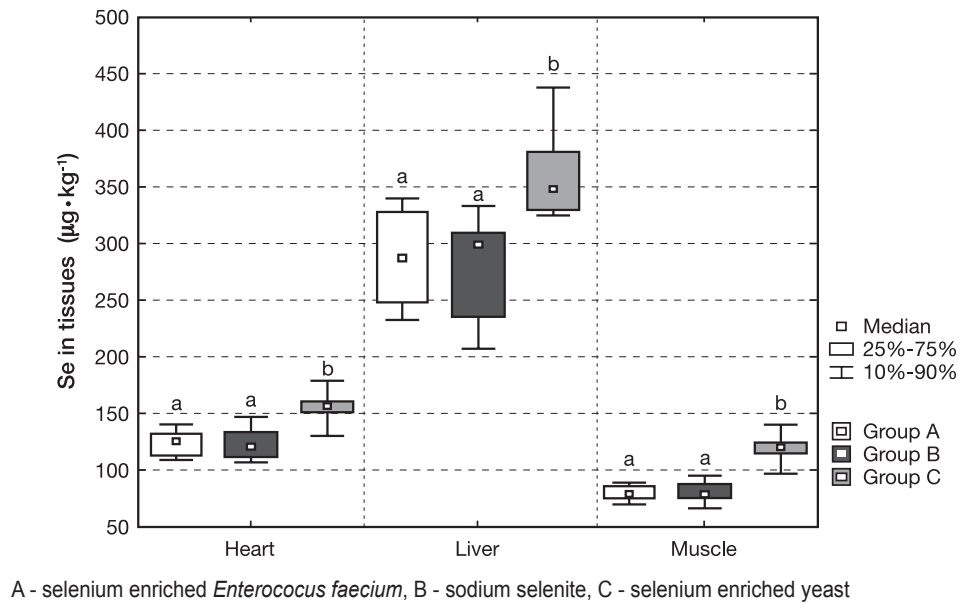

Fig. 3. Se concentration in tissues

Major carcass measurements and muscle characteristic are presented in Table 3 . We did not find any differences among the tested groups.

\section{Discussion}

E. faecium is a nonpathogenic bacteria which can colonize both the human and swine intestine and exert beneficial probiotic effects (Mego et al. 2005). Moreover it positively influences both local and systemic immunity. It has been documented that E. faecium stimulates phagocytosis of peripheral neutrophils and production of antibodies and intestinal IgA secretion (Mikeš et al. 1995). The combination with selenium enhances immunostimulatory properties of the E. faecium preparations (Ferenčík et al. 2000). $E$. faecium enriched with organic selenium has been used for example for the elimination of pathogenic bacteria of inflammatory bowel disease and colon cancer (Mego et al. 2005) and for the treatment of experimental adjuvant arthritis (Rovenský et al. 2002).

It has been demonstrated that E. faecium can metabolize inorganic selenite and incorporate selenium in an organic form (Tilton et al. 1967). The form of selenium present in the Seenriched $E$. faecium bacteria has not yet been characterized. There are so far no analytic methods available that can fully characterized the selenium kinds and their distribution in bacteria. As the utilization of Se by animals is influenced by the composition of seleno-amino acid analogues, the feeding experiments in animals can bring important information. 


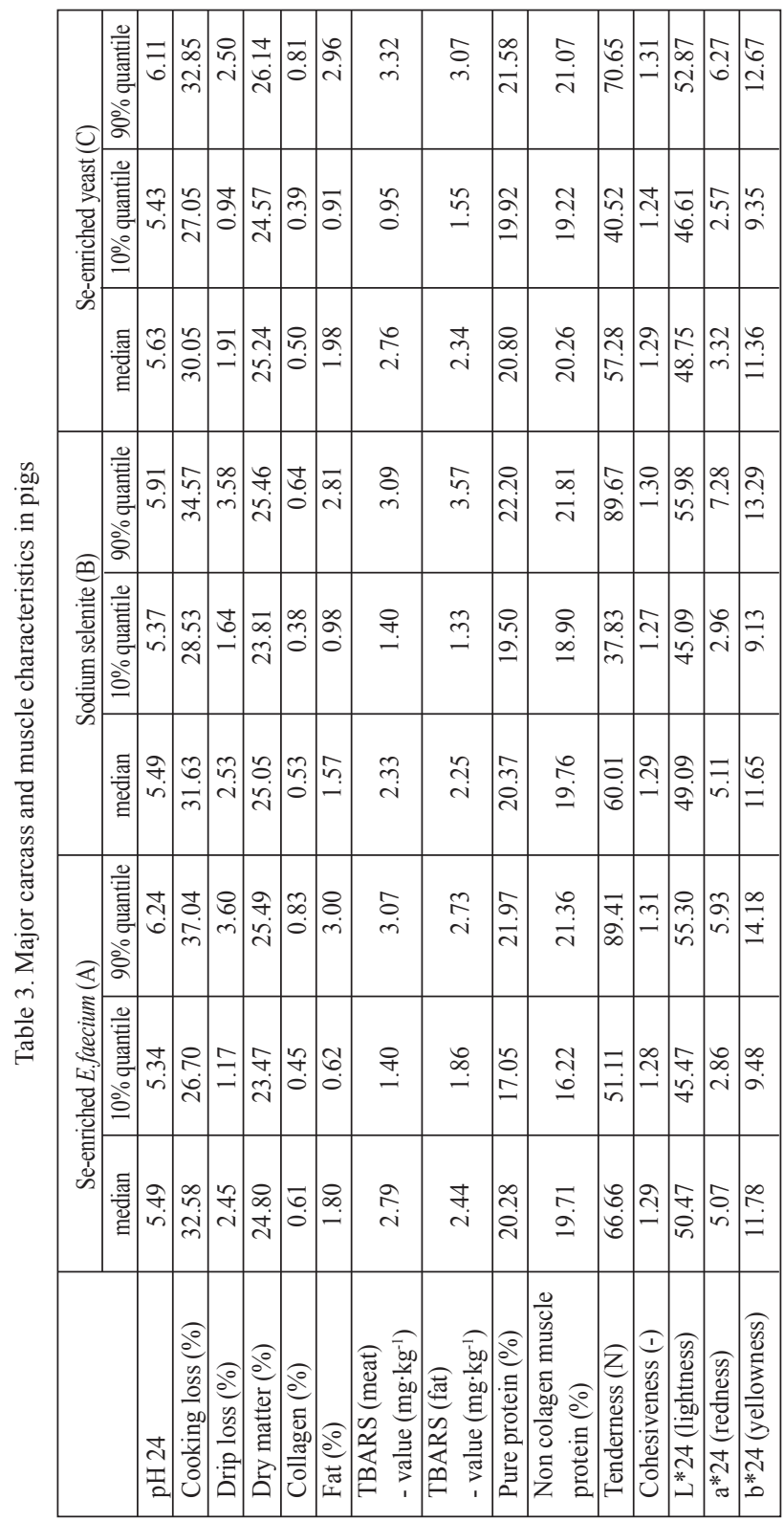

Selenomethionine is incorporated non-specifically into body proteins in place of methionine (McConnel and Hoffman 1972). Contrary to selenomethionineselenocystein is not incorporated non-specifically to proteins and it follows the same metabolic pathway as selenite (Schrauzer 2000). The use of Se-enriched E. faecium resulted in the Se tissue accumulation lower than in Se-enriched yeast group and in the accumulation comparable to sodium selenite group. Therefore it can be suggested that selenomethionine in the E. faecium represents smaller part and the selenocystein higher part of seleno-amino acid analogs.

No differences in GSH-Px serum activities were found among the groups supplemented with different form of selenium. This indicates that both inorganic and organic Se forms are an adequate source for GSHPx synthesis.

No effects of different Se sources on meat-quality traits were found in our study. This is consistent with the findings of Wolter et al. (1999) and our previous studies (Svoboda et al. 2009a; Svoboda et al. 2009b) and contradictory to Mahan et al. (1999) who reported a negative effect of selenite on drip loss and meat color.

It can be concluded that the Se-enriched E. faecium represents an alternative selenium source for pigs. It produces selenium accumulation in muscle tissue comparable to inorganic sodium selenite and it does not influence meat quality traits.

\section{Využití selenem obohacené baktérie Enterococcus faecium jako alternativního zdroje pro výkrmová prasata}

CílemexperimentubylozhodnotitvlivkrmeníselenemobohacenýchbakteriíEnterococcus faecium na koncentrace selenu ve svalovině a na ukazatele kvality masa. Byly použity 
skupiny prasat, jejichž krmivo bylo suplementováno selenem obohacenými baktériemi E. faecium $(\mathrm{n}=12)$, seleničitanem sodným $(\mathrm{n}=12)$, selenem obohacenými kvasnicemi $(\mathrm{n}=12)$. Testované krmné směsi byly krmeny po dobu 3 měsíců před odvezením prasat na jatky. Selen byl přidáván do krmiva v dávce $0,3 \mathrm{mg} \cdot \mathrm{kg}^{-1}$. Koncentrace selenu ve svalovině prasat po krmení selenem obohacené baktérie E. faecium, byly srovnatelné se seleničitanem sodným a byly nižší $(p \leq 0,05)$ ve srovnání se selenem obohacenými kvasnicemi. Koncentrace selenu a aktivita GSH-Px v krevním séru jednotlivých skupin prasat byly srovnatelné. Mezi skupinami prasat nebyly zjištěny žádné rozdíly v kvalitě svaloviny. Selenem obohacené baktérie E. faecium lze doporučit jako alternativní zdroj selenu pro prasata ve výkrmu se srovnatelnou účinností jako při použití seleničitanu sodného.

\section{Acknowledgements}

The study was supported by the projects MSM 6215712403 and MSM 6215712402.

\section{References}

Beck MA, Nelson HK, Shi Q, Van Dael P, Schriffin EJ, Blum S, Barcley D, Levander OA. 2001: Selenium deficiency increases the pathology of an influenza virus infection. J Fed Am Soc Exp Bio 15: 1846-1848

Castellini C, Mugnai C, Dal Bosco A. 2002: Effect of organic production system on broiler carcass and meat quality. Meat Sci 60: 219-225

Duffield-Lillico AJ, Slate EH, Reid ME et al. 2003: Selenium supplementation and secondary prevention of nonmelanoma skin cancer in randomized trial. J Natl Cancer Inst 95: 1477-1481

Fajt Z, Drábek J, Steinhauser L, Svoboda M 2009: The significance of pork as a source of dietary selenium-an evaluation of the situation in the Czech Republic. Neuroendocrinol Lett 30( Suppl 1): 17-21

Ferenčík M, Mikeš Z, Ebringer L, Jáhnová E, Čižnár I 2000: Immunostimulatory and other beneficial health effects of lactic acid bacteria. Bratisl Lek Listy 101: 51-53

Jang YD, Choi HB, Durosoy S, Schlegel P, Choi BR, Kim YY 2006: Comparasion the Se bioavailability of organic Se sources in growing-finishing pig. XII ${ }^{\text {th }}$ AAAP Animal Science Congress, Korea

Kadrabová J, Mad'arič A, Ginter E 1996: Determination of the daily selenium intake in Slovakia. Bio Trace Ele Res 61: 277-286

Lindberg P, Tanhuanpää E, Schulman A, Garry-Andersson AS 1972: Tissue selenium in pigs with dietetic microangiopathy (MAP, "mulberry heart"). Acta Vet Scand 13: 238-241

Mahan DC, Cline TR, Richert B 1999: Effect of dietary levels of selenium-enriched yeast and sodium selenite, serum glutathione activity, carcass characteristics and loin quality. J Anim Sci 77: 2172-2179

Mahan DC, Parrett NA 1996: Evaluating the efficacy of Se enriched yeast and inorganic selenite on tissue retention and serum glutathione peroxidase activity in grower finisher swine. J Anim Sci 74: 2967-2974

Mahan DC, Peters JC 2004: Long-term effects dietary organic and inorganic selenium sources and levels on reproducing sows and their progeny. J Anim Sci 82: 1343-1358

McConnell KP, Hoffman JL 1972: Methionine-selenomethionine parallels in rat liver polypeptide chain synthesis. Fed Proc 31: 691

Mego M, Májek J, Končeková R, Ebringer L, Čierniková S, Rauko P, Kováč M, Trupl J, Slezák P, Zajac V 2005 : Intramucosal bacteria in colon cancer and their elimination by probiotic strain Enterococcus faecium M-74 with organic selenium. Folia Microbiol 50: 443-447

Mikeš Z, Ferenčík M, Jáhnová E, Ebringer L, Čižnár I 1995: Hypocholesterolemic and immunostimulatory effects of orally applied Enterococcus faecium M-74 in man. Folia Microbiol 40: 639-646

Paglia DE, Valentin WN 1967: Studies on quantitative and qualitative characterization of erythrocyte glutathione peroxidase. J Lab Clin Med 70: 158-169

Rayman MP 2000: The importance of selenium to human health. Lancet 356: 233-241

Schrauzer GN 2000: Selenomethionine: a review of its nutritional significance, metabolism and toxicity. J Nutr 130: $1653-1656$

Rovensky J, Švík K, Stančíková M, Ištok R, Ebringer L, Ferenčík M 2002: Treatment of experimental adjutant arthritis with the combination of methotrexate and lyophilized Enterococcus faecium enriched with organic selenium. Folia Microbiol 47: 573-578

Sunde RA 1994: Intracellular glutathione peroxidases-structure, regulation and function. Sel Bio Hum Health 45-77

Svoboda M, Kotrbáček V, Ficek R, Drábek J 2009a: Effect of organic selenium from Se-enriched alga (Chlorella spp.) on selenium transfer from sows to their progeny. Acta Vet Brno 78: 373-377

Svoboda M, Saláková A, Fajt Z, Kotrbáček V, Ficek R, Drábek J 2009b: Efficacy of Se enriched alga Chlorella spp. and Se-enriched yeast on tissue selenium retention and carcass characteristics in finisher pigs. Acta Vet Brno 78: 579-588 
Taylor JB, Finley JW, Caton JS 2005: Effect of chemical form of supranutritional selenium on selenium load and selenoprotein activities in virgin, pregnant, and lactating rats. J Anim Sci 83: 422-429

Tilton RC, Gunner HB, Litsky W 1967: Physiology of selenite reduction by enterococci I.: Influence of enviromental variables. Can J Microbiol 13: 1175-1182

Wolter B, Ellis M, McKeith FK, Miller KD, Mahan DC 1999: Influence of dietary selenium source on growth performance, and carcass and meat quality characteristics in pigs. Can J Anim Sci 79: 119-121 